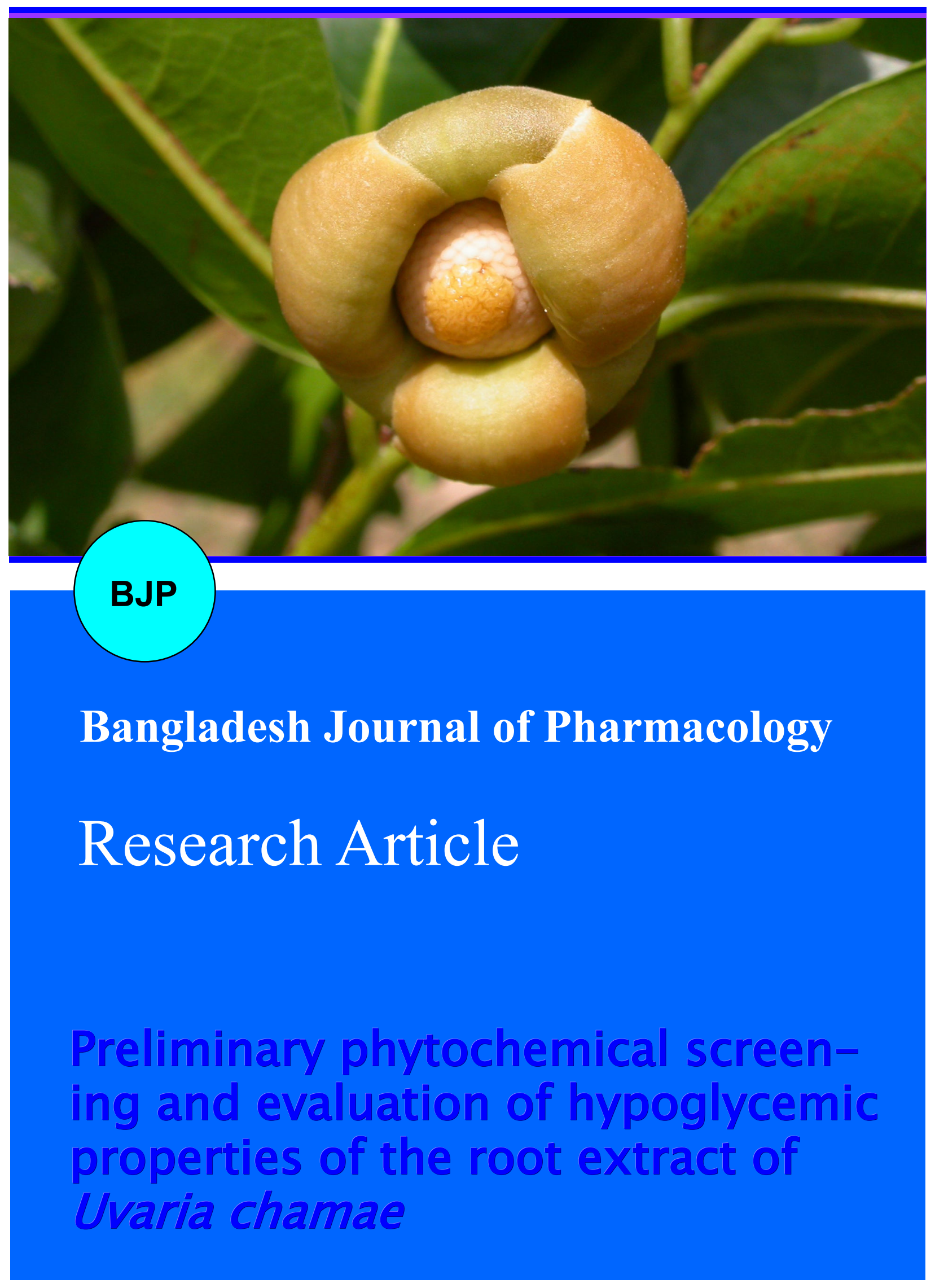




\title{
Preliminary phytochemical screening and evaluation of hypoglycemic properties of the root extract of Uvaria chamae
}

\author{
Emordi Jonathan Emeka1, Agbaje Esther Oluwatoyin², Oreagba Ibrahim Adekunle² and \\ Iribhogbe Osede Ignis ${ }^{1}$
}

${ }^{1}$ Department of Pharmacology and Therapeutics College of Medicine, Ambrose Ali University Ekpoma, Nigeria; ${ }^{2}$ Department of Pharmacology, Therapeutics and toxicology, College of Medicine of the University of Lagos, Nigeria.

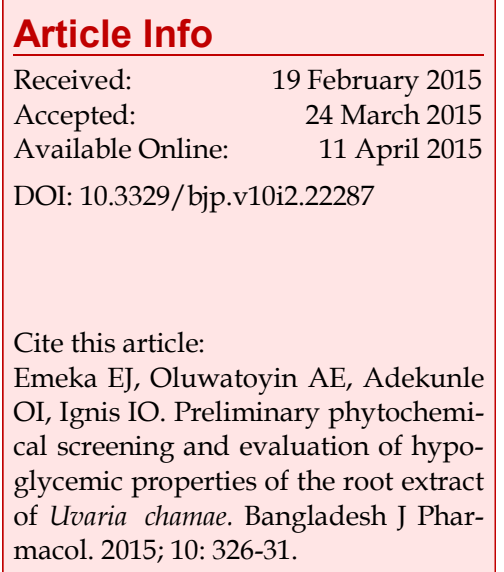

\section{Abstract}

The purpose of this study is to evaluate the hypoglycaemic properties and preliminary phytochemical screening of Uvaria chamae. The hypoglycaemic properties of $U$. chamae was assessed on normoglycaemic rat that received single dose of the extract at 250 and $500 \mathrm{mg} / \mathrm{kg}$ body weight and blood glucose levels estimated at 2, 4, and 6 hours (single dose study). The hypoglycaemic property of the extract was also evaluated in normoglycemic rats by oral glucose tolerance test. Phytochemical screening of the extract for the presence of secondary metabolites was performed with standard methods. The extract showed a significant $(\mathrm{p}<0.05)$ reduction in blood glucose levels at 2 and 6 hours compared to control. The oral glucose tolerance test result also showed a significant decrease $(p<0.05)$ in blood glucose levels. The study showed that the extract, $U$. chamae has hypoglycaemic properties which may be accounted for by the presence of the phytochemicals.

\section{Introduction}

Diabetes mellitus has been described as a metabolic disorder of multiple etiologies characterized by chronic hyperglycaemia with disturbances of carbohydrate, fat and protein metabolism resulting from defects in insulin secretion, insulin action or both (Walter, 1977; Albert et al., 1998; Kumar and Clark, 2005).

It is a major degenerative disease in the world today afflicting many lives both in the developed and developing countries (Mbaka et al., 2012). It is usually irreversible and its late complications result in reduced life expectancy and major health loss (Kumar and Clark, 2005). Currently diabetes is controlled by diet, exercise, oral hypoglycaemic agents and insulin therapy (Mallick et al., 2007). The high level of treatment failures, unpleasant side effects and enormous cost associated with oral anti-diabetic drugs have generated an urgent need and desire for alternative treatments (Suneetha et al., 2010). The preferred choice of plant medicine by many might not be unconnected with the historical successes recorded in the use of herbal product in traditional system of medicine in managing diabetes mellitus (Mbaka et al., 2012). Besides, herbal formulations were observed to have fewer side effects and less toxic because of their rich natural source. Based on these and the support provided for its practice by the World Health Organization, several scientific investigations are being conducted with the view of identifying new active ingredient of natural source that would be more effective in the treatment of diabetes mellitus and diabetic complications (WHO, 1980). Uvaria chamae is a medicinal plant that belongs to the family, Annonaceae. It is a climbing plant commonly found in West Africa (Irvin, 1961; Okwu, 2004). In this region of the world, it is identified by numerous names such as: Ogholo by Esan people of Edo state, Ayiloko by the Igalas, Kaskaifi by the Hausas, Oko oja by the Yorubas in Nigeria and Akotompo by Fulafainte people of Ghana (James et al., 2013). It has been reported to 
have antivenom activity (James et al., 2013). The antibacterial and antifungal activities have also been reported (Okwu et al., 2004). However, no scientific study has been conducted on the anti-diabetic activity of this plant. The aim of this study is to evaluate the hypoglycaemic properties and preliminary phytochemical screening of $U$. chamae.

\section{Materials and Methods}

\section{Plant materials}

The roots of $U$. chamae were obtained from a farm in Uromi, Edo State, Nigeria. They were authenticated by a taxonomist, mr T.K Odewo, of Botany Department, University of Lagos. The voucher specimen with number LUH 3572 was deposited in the University herbarium.

\section{Preparation of the plant material for extraction}

The roots were washed with clean water to remove foreign materials, chopped into small pieces and dried in an oven at 45 degrees centigrade for four days. They were powdered to coarse particles with electric grinder. The root powder, weighing $500 \mathrm{~g}$, was extracted with $93.3 \%$ aqueous ethanol by maceration with frequent stirring for 5 days. The extract was filtered using Whatman filter paper No. 4 and concentrated with a rotary evaporator. The concentrated extract was dried in an oven at 40 degrees centigrade to obtain $22.4 \mathrm{~g}$ dry residue $(4.5 \%$ yields).

\section{Animals}

Swiss mice (20-25 g) and Wistar rats $(160 \pm 20 \mathrm{~g})$ of both sexes were obtained from the Laboratory Animal Center, College of Medicine, University of Lagos, IdiAraba and were kept under standard environmental condition of 12/12 hours light/dark cycle. They were housed in cages (5 animals per cage), maintained on standard animal pellets (Pfizer Feeds Plc, Nigeria), and provided with water ad libitum. They were allowed to acclimatize for seven days to the laboratory conditions before the experiment. The use and care of the animals, and the experimental protocol were in strict compliance with the Institute of Laboratory Animals Research (ILAR) guidelines on the use and care of animals, in experimental studies (ILAR, 1996).

\section{Acute toxicity study}

The toxicity study was carried out using 35 (male and female) Swiss albino mice (each weighing 20-25 g). The animals were randomly distributed into a control group and six treated groups, containing five animals per group. After fasting the animals overnight, the control group was given $0.4 \mathrm{~mL}$ of acacia (2\%) suspension orally. while each treated group received oral solution of the extract prepared with $2 \%$ acacia in the doses of
1.0, 2.5, 5.0, 10.0, and 15.0 and $20.0 \mathrm{~g} / \mathrm{kg}$ body weight respectively. The animals were observed continuously for the first 4 hours and then for each hour for the next 24 hours and at 6 hourly interval for the next 48 hours after administering the extract to observe any death or changes in general behaviour and other physiological activities (Ayub et al., 1997; Bürger et al., 2005). The dose that results in $50 \%$ mortality $\left(\mathrm{LD}_{50}\right)$ was then determined (Figure 1).

\section{Prelimnary phytochemical screening}

Phytochemical screen-ing of the extract for the presence of secondary metabolites was performed with standard methods using the following reagents and chemicals: alkaloids with Mayer's reagent and Dragendorff's reagent (Farns-worth, 1966; Harborne, 1998), flavonoids with the use of $10 \%$ lead acetate and $20 \%$ sodium hydroxide (Trease and Evans 1983; Sofowora 1993), tannins with $5 \%$ ferric chloride solution (Yadav and Agarwala, 2011) and saponins with ability to produce suds (Houghton and Raman, 1998). Terpenes with Liebermann-Buchard test consisting of a mixture of glacial acetic acid and sulphuric acid (Shoppee, 1964). Terpenoids with a mixture of extract and chloroform and concentrated $\mathrm{H}_{2} \mathrm{SO}_{4}$ (Sofowora, 1993).

\section{Assessment of hypoglycemic properties of U. Chamae (single dose study)}

Fifteen rats were randomly selected into 3 groups, 5 rats per group. The rats were fasted over-night. Fasting blood glucose levels of each group was evaluated. Group I, untreated control was given $0.5 \mathrm{~mL}$ of $2 \%$ Acacia, while Group II and III were given the extract, orally at doses of $250 \mathrm{mg} / \mathrm{kg}$ and $500 \mathrm{mg} / \mathrm{kg}$ respectively. Blood samples were collected for estimation of Blood glucose level from the tail vein at 2, 4 and 6 hours after giving the extract (Santosh et al., 2007).

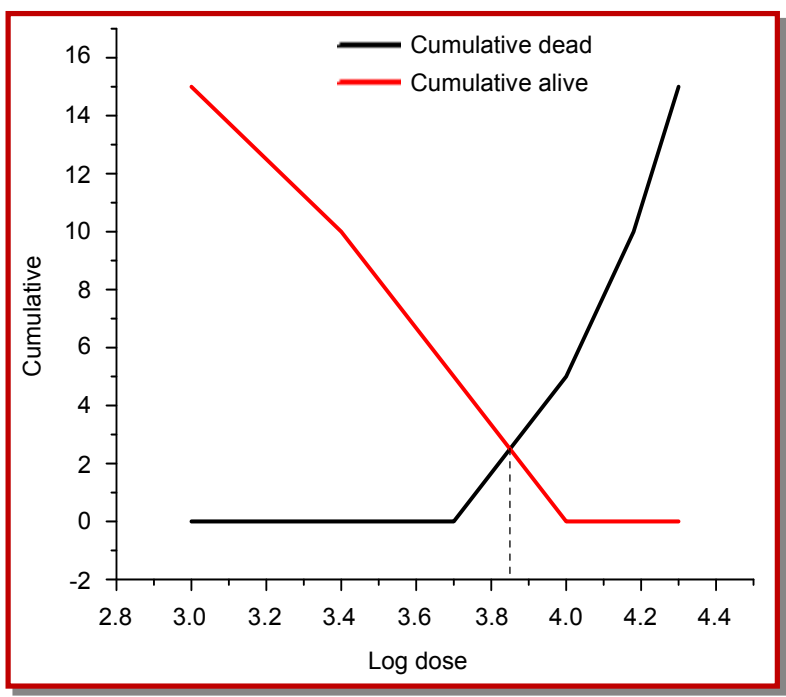

Figure 1: Determination of $\mathrm{LD}_{50}$ using cumulative dead of the mice and cumulative mice that are alive (Colegate et al., 1993) 


\begin{tabular}{|lcccccc|}
\hline \multicolumn{7}{c|}{ Table I } \\
\hline \multicolumn{7}{c}{ Oral acute toxicity of root extract of Uvaria chamae in mice } \\
\hline Group & Dose $(\mathrm{mg} / \mathrm{kg})$ & Log dose & Mice alive & Dead mice & Cumulative alive & Cumulative dead \\
\hline I & 20,000 & 4.30 & 0 & 5 & 0 & 15 \\
II & 15,000 & 4.18 & 0 & 5 & 0 & 10 \\
III & 10,000 & 4.0 & 0 & 5 & 0 & 5 \\
IV & 5,000 & 3.7 & 5 & 0 & 5 & 0 \\
V & 2,500 & 3.4 & 5 & 0 & 10 & 0 \\
VI & 1,000 & 3.0 & 5 & 0 & 15 & 0 \\
\hline
\end{tabular}

Control received $0.4 \mathrm{~mL}$ of $2 \%$ acacia; Group I, II, III, IV, V, VI: 20,000, 15,000, 10,000, 5,000, 2,500, 1,000 mg/kg respectively; n=5

\begin{tabular}{|c|c|c|c|c|}
\hline \multicolumn{5}{|c|}{ Table II } \\
\hline \multicolumn{5}{|c|}{ Assessment of hypoglycaemic properties of Uvaria chamae } \\
\hline \multirow[t]{3}{*}{ Group } & \multicolumn{4}{|c|}{ Blood glucose levels $(\mathrm{mg} / \mathrm{dL})$} \\
\hline & Pre-treatment & & Post-treatme & \\
\hline & 0 (FBG) & 2 hours & 4 hours & 6 hours \\
\hline Group I & $62.2 \pm 2.5$ & $63.8 \pm 2.4$ & $53.8 \pm 2.5$ & $66.3 \pm 7.0$ \\
\hline Group II & $57.7 \pm 1.6$ & $53.3 \pm 1.9^{a}$ & $50.4 \pm 1.5$ & $30.4 \pm 1.1^{\mathrm{a}}$ \\
\hline Group III & $60.8 \pm 2.4$ & $52.7 \pm 1.5^{\mathrm{a}}$ & $52.1 \pm 1.8$ & $36.6 \pm 3.3^{a}$ \\
\hline
\end{tabular}

Mean \pm SEM; $n=5$; ap<0.05; bp<0.01 vs. control group; Group I: control received $0.5 \mathrm{~mL}$ of $2 \%$ acacia; Group II, III: 250 , 500 mg/kg respectively

\section{Effect of the extract on oral glucose tolerance test}

Normal rats male and female were fasted over night and divided into four groups of five rats each. Blood samples were collected from the tail veins of the rats to estimate the fasting blood glucose levels. Group 1, the control, was given $0.5 \mathrm{~mL}$ of $2 \%$ Acacia and group 2, 3 and 4 were given 100, 250 and $500 \mathrm{mg} / \mathrm{kg}$ of extract respectively. Thirty minutes after administering the extract, the three groups were administered $40 \%(\mathrm{w} / \mathrm{v})$ glucose at a dose of $1 \mathrm{~mL} / 100 \mathrm{~g}$ body weight orally (Ogbonnia et al., 2011). Blood glucose levels monitored at 30, 60 and $120 \mathrm{~min}$ intervals and reported as the average glucose level of each group.

\section{Statistical analysis}

Analysis of data was done using GraphPad Prism 6. One-way analysis of variance and t-test were used to compare means. Means \pm SEM are shown in all tables. Level of significance was set at $\mathrm{p}<0.05$ or $\mathrm{p}<0.01$.

\section{Results}

In the acute toxicity study (Table I), there was no death among the animals that received 1,000-5,000 mg/ $\mathrm{kg}$ body weight of the extract. The animals that received $10,000-20,000 \mathrm{mg} / \mathrm{kg}$ body weight of the extract died within 24 hours. The $\mathrm{LD}_{50}$ of the drug was calculated to be $7,080 \mathrm{mg} / \mathrm{kg}$ body weight.

Table II shows the hypoglycaemic effects of a single oral administration of two doses 250 and $500 \mathrm{mg} / \mathrm{kg}$ body weight of the root extracts of $U$. chamae in normal healthy rats. These doses showed significant reduction $(p<0.05)$ in blood glucose levels at 2 and 6 hours compared to control. Rats treated with $250 \mathrm{mg} / \mathrm{kg}$ of the extract showed a maximum reduction of $54.2 \%$ in blood glucose level after 6 hours of oral administration. However, the reduction in blood glucose level at the dose of $250 \mathrm{mg} / \mathrm{kg}$ body weight at 2 and 4 hours was 16.5 and $6.3 \%$ respectively. Also, rats treated with 500 $\mathrm{mg} / \mathrm{kg}$ of the extract showed a maximum reduction of $44.8 \%$ in blood glucose level after 6 hours of oral administration. The reduction in blood glucose level at the dose of $500 \mathrm{mg} / \mathrm{kg}$ body weight at 2 and 4 hours was 17.4 and $3.2 \%$ respectively.

Figure 2 shows the summary of the oral glucose tolerance test. Following oral glucose load in the control group, the rise in blood glucose level reached a peak at $30 \mathrm{~min}$ of glucose load. Decrease in blood glucose level occurred after $30 \mathrm{~min}$ but the blood glucose level failed to return to baseline after $120 \mathrm{~min}$. There was a significant decrease $(\mathrm{p}<0.05)$ in blood glucose levels at 30,60 and 120 min with a percentage decrease of 57.5, 28.6 and $41.4 \%$ respectively in the group of rats treated with $500 \mathrm{mg} / \mathrm{kg}$ dose of extract compared with control.

The preliminary phytochemical screening of the root extract of $U$. chamae revealed the presence of flavonoids, alkaloids, cardiac glycosides, terpenoid and terpenes, saponin, tannin proteins and sugars (Table III). 


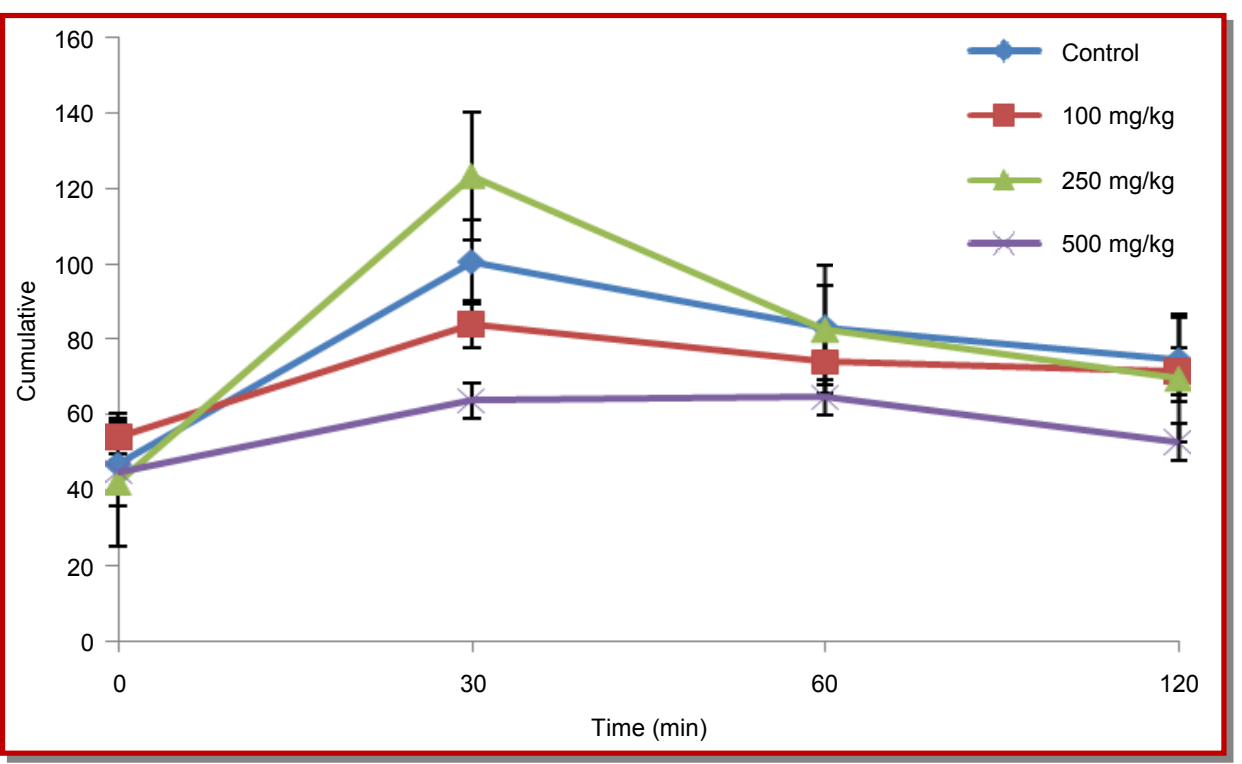

Figure 2: Oral glucose tolerance test

\begin{tabular}{|c|c|}
\hline \multicolumn{2}{|c|}{ Table III } \\
\hline \multicolumn{2}{|c|}{$\begin{array}{l}\text { Qualitative analysis of phytochemcal constituents } \\
\text { of root extract of Uvaria chamae }\end{array}$} \\
\hline Compounds & Presence \\
\hline Alkaloids & +++ \\
\hline Flavanoids & ++ \\
\hline Cardiac glycosides & + \\
\hline Terpenoids and terpenes & + \\
\hline Saponin & + \\
\hline Tannin & ++ \\
\hline Protein & + \\
\hline Sugar & + \\
\hline
\end{tabular}

+++ appreciable amount; ++ moderate amount; + trace amount

\section{Discussion}

The major goals in the treatment of diabetes has been to keep both short- and long-term glucose levels within acceptable limits, thereby reducing the risk of long-term complications (Park et al., 2009). This could be achieved by optimizing both fasting blood glucose and postprandial glucose levels which have been found to be very important in achieving near normal glucose levels. Postprandial glucose levels have been reported to serve as a better maker of glycemic control than fasting blood sugar levels (Park et al., 2009).

Drugs that reduce post-prandial hyperglycemia by suppressing hydrolysis of starch have been found useful in the control of diabetes mellitus (Tundis et al., 2010; Kazeem et al., 2013a). Many herbal extracts have been reported for their anti-diabetic activities and are currently being used in traditional medicines for the treatment of diabetes. However, such medicinal plants have not yet gained much importance as medicines due to lack of sustained evidence (Sudha et al., 2011).

The results of this study showed that the median lethal dose $\left(\mathrm{LD}_{50}\right)$ of the root extract was determined to be $7.08 \mathrm{~g} / \mathrm{kg}$ body weight translating to $490 \mathrm{~g}$ dose for human adult. According to Loomis and Hayes (1996), the extract can be classified as being practically nontoxic since this value is much higher than Organization for Economic Cooperation and Development (OECD) toxicity index of $2 \mathrm{~g} / \mathrm{kg}$ (Walum, 1998; OECD, 2001). Therefore, the extract may be considered to be safe for consumption.

This study revealed that the rats treated with 250 and $500 \mathrm{mg} / \mathrm{kg}$ of the extract had maximum reduction of 54.15 and $44.80 \%$ in blood glucose level after 6 hours of oral administration respectively. The extract exerted hypoglycaemic activity by decreasing the blood glucose level significantly. Low blood glucose level reduces the risk of complications associated with diabetes (Attele et al., 2002; Emordi et al., 2014).

The result of oral glucose tolerance test showed that there was a significant decrease $(p<0.05)$ in blood glucose levels at 30,60 and 120 min with a percentage decrease of $57.5,28.6$ and $41.4 \%$ respectively in the group of rats treated with $500 \mathrm{mg} / \mathrm{kg}$ dose of extract compared with control.

Insulin release in response to a glucose load occurs in two phases in humans and in rodents. The early phase peaks within the first $15-30 \mathrm{~min}$ and is responsible for limiting the initial rise in glucose upon meal ingestion. The late phase of insulin secretion occurs later than 30 min after a meal, and may persist for several hours. This delayed burst of insulin secretion is responsible for returning glucose to baseline fasting levels. In the face of insulin resistance, the late phase of insulin secretion 
persists for an extended period and contributes to excessive insulin levels even after a return to the fasted state, resulting in fasting hyperinsulinemia (Oda, 2012). From this study, the marked reduction in plasma glucose concentration may be as a result of increased release of insulin from beta cells. This may also account for the hypoglycemic activity of the extract.

The health benefits of medicinal plants are attributed in part to their unique phytochemical composition $(\mathrm{Okwu}$, 2005). Phytochemicals are secondary metabolites of plant origin which act as anti-oxidants and stimulate the protective enzymes in the liver or block damage to genetic materials (Okwu, 2004). They prevent the occurrence of oxidative chemical species, stimulate antioxidant repairing mechanism and scavenging capacity for free radicals in the system.

Flavonoids are phenolic compounds that possess antioxidant and anti-diabetic potentials due to the presence of hydroxyl groups that confer scavenging ability on them (Mayur et al., 2010). Research has shown that many plants containing flavonoids have been used for the treatment of diabetes (Meiselman et al., 1976; Choi et al., 1991; Hassig et al., 1999).

Tannins induce phosphorylation of the insulin receptors as well as translocation of glucose transporters 4 (GLUT-4), the protein factor involved in the signaling pathway of insulin-mediated glucose transport and the inhibition of the expression of key gene for adipogenesis thereby helping to reduce blood glucose level without increasing adiposity (Liu et al., 2005).

Suba and co-workers reported in 2004 that tannin has anti-diabetic activity.

One of the most important carbohydrate-splitting enzymes is the maltase-glucoamylase which helps to break-down dietary disaccharides into monosaccharide in the small intestine. If its activity is inhibited, the digestion and absorption of monosaccharide can be slowed down, decreasing the post-prandial hyperglycaemia. The potential therapeutic use of polyhydroxylated alkaloids in the treatment of type-2 diabetes due to their ability to inhibit maltaseglucoamylase has been reported (Shang et al., 2013). It is therefore possible that the phytochemicals present in the root extract of $U$. chamae may be responsible for the observed hypoglycemic activity.

The $\mathrm{LD}_{50}$ value $7.1 \mathrm{~g} / \mathrm{kg}$ obtained was a clear indication that $U$. chamae is safe for use. The study showed that the root extract of $U$. chamae has hypoglycaemic activity which may be as a result of increased release of insulin from beta cells. The hypoglycaemic activity of the extract may also be accounted for by the presence of several bioactive compounds like flavonoids, tannins and alkaloids.

\section{Acknowledgement}

The authors wish to thank Mr. M. E. Idemudia of Idumuune Quarters, Uromi, Edo State, Nigeria, for his assistance in plant collection.

\section{References}

Albert RGMM, Zimmet PZ. Definition, diagnosis and classification of diabetes mellitus and its complications. Part 1, Provisional report of WHO consultation. Diabetes Med. 1998; 15: 539-53.

Attele AS, Zhou Y, Xie J, Wu JA, Zhang L, Dey L, Pugh W, Rue PA, Polonsky KS, Yuan C. Anti-diabetic effects of Panax ginseng berry extract and the identification of an effective component. Diabetes 2002; 51: 1851-58.

Ayub SMA, Garg SK, Garg KM. Subacute toxicity studies on pendimethalin in rats. Indian J Pharmacol. 1997; 29: 322-24.

Burger C, Fischer DR, Cordenuzzi DA, Batschauer de Borba AP, Filho VC, Soares dos Santos AR. Acute and subacute toxicity of the hydroalcoholic extract from Wedelia paludosa in mice. J Pharmaceut Sci. 2005; 8: 370-73.

Choi JS, Yokozawa T, Oura H. Improvement of hyperglycaemia and hyperlipemia in streptozotocin-diabetic rats by a methanolic extract of Prunus davidiana stems and its main component, Prunin. Planta Medica. 1991; 57: 208-11.

Colegate SM, Molyneux RJ. Bioactive natural products detection, isolation and structural determination. $1^{\text {st }}$ ed. USA, CRC Press, 1993, p 447.

Emordi EJ, Ogbonnia OS, Olayemi OS, Anyika NE, Iribhogbe IO. Hypoglycaemic and hypolipidemic effects of the phytomedicine- bee honey and Musa paradisiaca extract in alloxan-induced diabetic rats. Int J Herbs Pharmacol Res. 2014; 3: 16-23.

Farnsworth RN. Review on biological and phytochemical screening of plants. J Pharm Sci. 1966; 55: 225-76.

Harborne JB. Phytochemical methods: A guide to modern techniques of plant analysis. $3^{\text {rd }}$ ed. London, Chapman and Hall, 1998, p 235.

Hassig A, Liang WX, Schwabl H, Stampfli K. Flavonoids and tannins: Plant-based anti-oxidants with vitamin character. Med Hypotheses. 1999; 52: 479-81.

Houghton PJ, Raman A. Laboratory handbook for fractionation of natural extracts. London, Chapman and Hall, 1998, p 199.

Institute of Laboratory Animal Research. Commission on life science. National Research Council, 1996.

Irvin FR. Woody plants of Ghana with special reference to their uses. London, Oxford University Press, 1961, pp 19-20, 695.

James O, Godwin EU, Otini IG. Uvaria chamae (Annonaceae) plant extract neutralizes some biological effects of Naja nigricollis snake venom in rats. Bri J Pharmacol Toxicol. 2013; 4: $41-50$ 
Kazeem MI, Abimbola SG, Ashafa AOT. Inhibitory potential of Gossypium arboreum Linn leaf extracts on diabetes key enzymes (a-amylase and a-glucosidase). Bangladesh J Pharmacol. 2013; 8: 149-55.

Kumar P, Clark M. Diabetes mellitus and other disorders of metabolism. Kumar and Clark's Clinical Medicine. $6^{\text {th }}$ ed. Philadelphia, Elsevier Saunders, 2005, pp 1101-51.

Liu X, Kim J, Li Y, Li J, Liu F, Chen X. Tannic acid stimulates glucose transport and inhibits adipocyte differentiation in 3T3-Li cells. J Nutr. 2005; 135: 165-71.

Loomis TA, Hayes AW. Loomis's essentials of toxicology. $4^{\text {th }}$ ed California, Academic Press, 1996, pp 208-45.

Mallick C, Chatterjee K, Guhabiswas M, Ghosh D. Antihyperglycemic effects of separate and composite extract of root of Musa paradisiaca and leaf of Coccinia indica in streptozotocininduced diabetic male albino rat. Afr J Trad Cam. 2007; 4: 362-71.

Mayur B, Sandesh S, Shruti S, Sung-Yum S. Anti-oxidant and a -glucosidase inhibitory properties of Carpesium abrotanoides L. J Medicinal Plant Res. 2010; 4: 1547-53.

Mbaka GO, Ogbonnia SO, Banjo AE. Activity of Raphia hookeri root extract on blood glucose, lipid profile and glycosylated haemoglobin on alloxan-induced diabetic rats. J Morphol Sci. 2012; 29: 214-22.

Meiselman HL, Halpern BP, Dateo GP. Reduction of sweetness judgments by extracts from the leaves of Ziziphus jujuba. Physiol Behavior. 1976; 17: 313-17.

Oda E. Metabolic syndrome: Its history, mechanisms, and limitations. Acta Diabetol. 2012; 49: 89-95.

OECD. Acute oral toxicity: Fixed dose procedure. OECD Guide line for testing chemicals. 2001.

Ogbonnia SO, Mbaka GO, Anyika EN, Ladiju O, Igbokwe HN, Emordi JE, Nwakakwa N. Evaluation of anti-diabetics and cardiovascular effects of Parinari curatellifolia seed extract and Anthoclista vogelli root extract individually and combined on postprandial and alloxan-induced diabetic albino rats. Bri J Med Medical Res. 2011; 1: 146-62.

Okwu DE. Phytochemicals and vitamin content of indigenous species of South Eastern Nigeria. J Sustainable Agric Environ. 2004; 6: 30-37.
Okwu DE. Phytochemicals, vitamins and mineral content of to Nigerian medicinal plants. Int J Mol Med Adv Sci., 2005; 1: 375-81.

Park J, Bong H, Jeong H, Kim KY, Kim JY, Kwon O. Postprandial hypoglycemic effect of mulberry leaves in Gotokakizaki rats and counterpart control Wistar rats. Nutr Res Pract. 2009; 3, 272-78.

Santosh KS, Achyut NK, Prashant KR, Geeta W. Assessment of glycemic potential of Musa paradisiacal stem juice. Indian J Clin Biochem. 2007; 22: 48-52

Shang Q, Xiang J, Zhang H, Li Q, Tang Y. The effect of polyhydroxylated alkaloids on maltase-glucoamylase. PLoS ONE. 2013; 8: 1-5.

Sofowora A. Medicinal plants and traditional medicine in Africa. Ibadan, Nigeria, Spectrum Books limited, 1993, pp 191-289.

Suba V, Murugesan T, Rao BR, Ghosh L, Pal M, Mandal SC, Saha BP. Antidiabetic potential of Barleria lupulina extract in rats. Fitoterapia 2004; 75: 1-4.

Sudha P, Zinjarde SS, Bhargava SY, Kumar AR. Potent aamylase inhibitory activity of Indian Ayurvedic medicinal plants. BMC Compl Alternative Med. 2011; 11: 1-10.

Suneetha B, Sujatha D, Prasad KVSRG. Antidiabetic and antioxidant activities of stem juice of Musa paradisiaca on alloxan induced diabetic rats. Int J Adv Pharmaceut Sci. 2010; 1: 16776

Tundis R, Loizzo MR, Menichini F. Natural products as aamylase and a-glucosidase inhibitors and their hypoglycemic potential in the treatment of diabetes: An update. Minirev Med Chem. 2010; 10: 315-31.

Walter BJ. An introduction to the principles of disease. Philadelphia, USA, W. B. Saunders Company, 1977, pp 37475 .

Walum E. Acute oral toxicity. Environ Health Perspect. 1998; 106: 498.

World Health Organization. Expert committee on diabetes mellitus. (Technical Report, Series 646). Geneva, WHO, 1980.

Yadav RNS, Agarwala M. Phytochemical analysis of some medicinal plants. J Phytol. 2011; 3: 10-14. 